\title{
Technical and Economic Analysis of Solar Photovoltaic Water Pumps against Conventional Systems in Common Crops in Ilocos Sur, Philippines
}

\author{
Cherie Orpia $^{1}{ }^{*}$, Julius Orpia ${ }^{2}$, Milagros Liberato ${ }^{1}$ \\ ${ }^{1}$ Graduate School, Ilocos Sur Polytechnic State College, Sta. Maria, Ilocos Sur, Philippines \\ 2, Independent Researcher \\ * cherie.orpia@gmail.com
}

\begin{abstract}
Irrigation is a well-established procedure on many farms and is practiced around the world. However, typical irrigation systems consume a great amount of conventional energy using electric motors and generators powered by fuel. The cost of solar panels has been continually decreasing, which encourages its usage in various sectors, including agriculture, where irrigation is a crucial economic driver. The study analyzed and compared PV technology against conventional irrigation technology in common crops in Ilocos Sur. Equipment sizes were optimally determined using available irrigation requirements, rainfall data, farm area, and available equipment sizes in Ilocos Sur. Equipment sizing and economic analysis were based on one hectare of land. The cash flow analysis was conducted over an assumed equipment life of 20 years to be able to come up with levelized water pumping costs. Results showed that with typical farmland in Ilocos Sur, the farmland must be alternately planted with rice and corn to be able to be fully utilized all year round. The study showed that the solar pump installation has a heavy upfront investment cost compared to the conventional system. Due to no fuel and little to no maintenance needed, the solar pump turned out to be more economically feasible in the long run. In the 20-year life of both equipment, pumping one cubic meter of water using a solar pump is only PHP 1.35 while for gasoline, it is PHP 5.44 or around four times more expensive based on the prevailing cost at the time of the study.
\end{abstract}

Keywords

Solar Pump, Photovoltaic Pump, Water Pumping, Irrigation, Cost Analysis, Financial Analysis

\section{Introduction}

Water scarcity is becoming a major problem all around the world. It is attributable to water pollution, inadequate river flow and demand increase due to population growth and rapid urbanization [1]. Due to population growth triggering the change of land use due to agricultural land expansion, the world is in need of additional global freshwater resources [2].

Irrigation is a well-established procedure on many farms and is practiced on various levels around the world. This paves the way to crop diversification, at the same time increasing agricultural yields. However, typical irrigation systems consume a significant amount of conventional energy using electric motors and generators powered by fuel. Photovoltaic energy can be found in many applications in agriculture, providing electrical energy in various cases, particularly in areas without an electric grid. Solar energy is the most abundant source of energy in the world. Solar power is not only an answer to today's energy crisis but also an environmentally friendly form of energy. Photovoltaic (PV) generation is an efficient approach to using solar energy. Solar panels (an array of photovoltaic cells) are now extensively used for running streetlights, for powering water heaters and to meet domestic loads. The cost of solar panels has continuously been decreasing, which encourages its usage in various sectors. One of the applications of this technology is used in irrigation systems for farming [1]. Solar-powered irrigation systems can be a suitable alternative for farmers in the present state of energy crisis in the Philippines. This is a green way for energy production, which provides free energy once an initial investment is made.

In most rural areas in Ilocos Sur, where there is no ready source of water for irrigation, water is usually pumped to the farm through a diesel or gasoline engine. Due to the size of farm areas, the 
more common engine used is the gasoline-fired ones. Farmers then have no other choices than to expect the use of these engines for irrigation. An electric pump is an option, but laying hundreds of meters of wire to the farm poses many risks and downsides: the wires are expensive, possible theft, and electricity source are far. Gasoline engines are proven to be reliable as it has been used for around half a century now.

Solar Panels, monocrystalline or polycrystalline have dropped $70 \%$ over the last seven years. Its efficiency has been steadily increasing up to recent years. It is forecasted that the electricity cost will soon rival the cost of coal in terms of kilowatt-hour basis. The downside is, however, that the energy can only be harnessed during the daytime.

Since Solar PV plants can only harness energy during the daytime, there is a need to store the energy captured during the day and be released only as soon as it is needed. Storage is on various forms like chemical (batteries), mechanical forms like pumped storage (water), compressed air, and flywheels. For irrigation purposes, water can be impounded on a higher elevation, pumped with water during daytime, and the water may be released on a future desired date.

For the benefit of the agricultural sector, the energy need can be synonymous with irrigation requirement as the conventional technology requires fuel and/or electricity to run the engines and motors of the pumps, alongside other farm machinery.

Solar energy is starting to enter the agricultural scenario thru the introduction of solar DC pumps in recent years. As the cost of Solar panels is dropping every year, there is a need to evaluate whether replacing the existing equipment with solar pumps and storage is worth the investment.

\section{Literature Review}

Solar power pumping is principally based on PV technology, which converts solar energy to electrical energy for lifting water at least $7 \mathrm{~m}$ head. A PV solar power pumping system consists of a PV array, a DC/AC motor, pump, water storage tank, Electrical wire, and water outlet. The benefits of solar pumping for farms and farmers are: easy energy supply and enhanced access to water for irrigation, improved yields and enlarged profits, enhanced crop resilience and food security and extra benefits for human health, education and poverty reduction [1]. Solar-powered water pumping technology is boosting smallholder income recently, while it has been positioned for decades due to cost reduction and the potential benefits of this technology.

Many references [2,3,4] discussed the feasibility of using the PV and diesel generator in driving the water pumping systems in remote and rural areas in different locations in the world. Imene Yahyaoui and et al.[5] get the optimized parameters of the PV water pumping system using algorithms depending on the site, load, and panel characteristics for a 10 ha land surface in the north of Tunisia. Ahmad Agus Setiawana et al. studies the development of a PV water pumping system to solve the water supply problem in Indonesia. [6] Francisco J. Chueco-Fernández and Ángel A. Bayod-Rújula [7] compared the cost-effectiveness to drive the water pumping system for irrigation purposes in remote areas in Chile using the diesel generator and the PV panels with the utility grid. In their analysis, they take into account the required investments, fuel, and pumping costs. The water pumping system driven by either PV panels or diesel generator for developing remote areas was also studied by Elham Mahmoud and Hossen El Nather [8] . They compared the feasibility of using the diesel units and the standalone PV generation taking into consideration the different parameters affecting the present value and the other costs of both systems. According to their study, they concluded that the cost of using diesel systems in water pumping is much higher than that of the PV system, and the water cost is more sensitive to the panels' prices than their life periods.

\section{Objectives}

1. Identify common crops in Ilocos and determine planting season and irrigation requirements. The common crops to be evaluated shall be based on planting interval schemes that would optimally use the lot throughout the year.

2. Calculate irrigation costs using conventional methods.

3. Calculate irrigation costs using Solar PV pumps. 
4. Determine required optimal Solar PV equipment and determine current market costs.

5. Determine operation and maintenance costs.

6. Compare the costs of conventional methods and the use of Solar PV pumps.

\section{Significance of the Study}

The study shall give a comparative financial analysis of adapting solar PV pumps in the irrigation of local crops in the province compared to conventional gasoline pumps, giving an overview to check if solar pumping is a financially viable option.

\section{Scope and Limitation of the study}

This study focused on the financial analysis of the use of gasoline pumps and solar water pumps as a source of irrigation in Ilocos Sur. No detailed technical analysis and design on equipment sizing were incorporated but instead relied on common practices and equipment used in the province and, at the same time, prevailing equipment, fuel, and operation costs.

\section{Materials and Methods \\ Common crops in Ilocos Sur determine planting season and irrigation requirements}

The study first investigated the common crops being planted in Ilocos Sur. The activity was conducted to properly simulate a good representative of a typical farm in the province. Once the common crops were identified. Planting and growing season were determined. A yearround schedule of crops was also prepared.

Irrigation requirements were determined. Initially, monthly rainfall was determined by taking recent rainfall data from PAGASA. This was matched with the irrigation requirements of the crops. Then the volume required for the water pumping formula is as follows:

required water for pumping

$$
\text { =irrigation requirement-rainfall }
$$

The data from PAGASA and kinds of literature taken provides the water requirements in terms of millimeters. This study evaluated 1 hectare of land. Thus, to convert millimeters of water to volume,
Total volume of water

$$
=\text { land area } x \text { depth of irrigation }
$$
$=1$ hectare $x$ [depth,mm], $=$ depth in $\mathrm{mm} \times 1000$

$\rightarrow$ units shall now be in cubic meters

Evapotranspiration is not included in the study as the amount is deemed negligible. In cases where the rainfall exceeds irrigation requirements, the water requirement was assumed zero and will not be stored.

\section{Theory and Calculation}

The common gasoline engine used in Ilocos Sur was identified. The nameplate capacity was identified and noted as follows:

Power output, HP or KW

Total Head, $m$

Volume flow rate, cubic meters per hour

The total head will only be noted for reference with the solar pump. The head requirement was evaluated on this research as the pump is already been proven and used by most farmers,

To compute for the fuel required in one (1) hour to operate the engine at max load, the total energy required was calculated first, thus

\section{Total Power required in $K W$} $=$ Total HP $x 0.746 \mathrm{~kW} / \mathrm{HP}$

Total Energy required

$$
=\text { Total } \mathrm{kJ} / \mathrm{s} \quad x 3600 \mathrm{~s}
$$

Total fuel required

$$
\text { = Total Energy/Efficiency/CalorificValue }
$$

Total fuel cost

$$
=\text { fuel required } x \text { fuel cost/liter }
$$

The calorific value and engine efficiency were taken in the literature. Fuel cost was taken from a local gas station.

The cashflow was taken on an annual basis up to year 20. It indicates all costs incurred, which would include equipment, fuel, manpower, and other expenses.

The total cost during the entire 20 year period shall be summed as well as the total volume being 
pumped. The actual cost of generating a volume of water shall be

water cost

$$
\begin{aligned}
& =(\text { Total volume pumped in } 20 \text { years }) \\
& /(\text { Total cost incurred in } 20 \text { years })
\end{aligned}
$$

\section{Calculate irrigation costs using solar water pumps}

To be able to size the required equipment for solar pumping properly, the required maximum daily water requirement was determined. This was based on the month with maximum water requirement divided by the number of days.

Based on the maximum daily requirement, the maximum capacity for the pump was determined.

\section{Required pump capacity$$
=(\text { Daily capacity }) /(\text { sun-hours })
$$

It is customary that the sun hours assumed is 4-5 hours. This represents the hours if the solar equipment is generating at maximum capacity equivalent to the actual output generated throughout the day,

Based on this, the required pump was chosen on the manufacturer catalog, it would also be able to match the head capacity of the gasoline engine commonly used.

A simulation of various scenarios of water tank capacity was made to fit the actual pumping and the actual dispatch of water, it must be ensured that the water tank will not dry out.

For the water flow output, the maximum flow was determined using the formulas

Maximum water speed

$$
v=\sqrt{(2 g h)}
$$

Where: $g=9.8 \mathrm{~m} / \mathrm{s} 2$

$\mathrm{h}=$ water head

and maximum Volume flow, Q

$$
\begin{aligned}
& Q=\text { Area } \times v \\
& Q=\left(\pi d^{\wedge} 2\right) / 4 \times v
\end{aligned}
$$

This value is the basis to ensure that that required flow during irrigation is achieved.

For the number of PV modules, the quantity was based on the pump capacity. The performance ratio of solar PV installations is usually at 70$80 \%$. A conservative value of $\mathrm{PR}=70 \%$, the required size is used:

\section{Required PV installation size $=($ Pump capacity $) /($ Estimated PR $)$}

A common size in the market was used. Polycrystalline type of PV modules will be preferred over monocrystalline because it is cheaper. The number of modules must have the capacity equal or exceeding the required PV installation size.

The cashflow was taken on an annual basis up to year 20, where it is assumed that the equipment will be close to its life end and be scrap value worth. It indicated all costs incurred, which would include equipment, fuel, manpower, and other expenses.

The total cost during the entire 20 year period was summed as well as the total volume being pumped. The actual cost of generating a volume of water is computed as

water cost

$$
\begin{aligned}
& =(\text { Total volume pumped in } 20 \text { years }) \\
& /(\text { Total cost incurred in } 20 \text { years })
\end{aligned}
$$

The comparison among conventional methods against the use of solar water pumps was directly compared to the levelized cost of production of water of both technologies.

\section{Crop Selection}

\section{Results and Discussion}

In 2012, the area planted to palay is 47,414 hectares with a total production of 209,977 MT or an average productivity level of 4.16 MT. This production exceeded the demand by $42,488.03$ MT, which is suitable for 116 days or four months supply.

The aggregate food crop production for the province attained a total of 386,015 MT for C.Y. 2012. Rice garnered the highest share of 209,977 MT or an equivalent of $54 \%$, followed by corn with a total production of 76,039 MT or $19.9 \%$ of the total output. Vegetable production was recorded at 75,298 MT or an equivalent of $19.7 \%$ of the total production. Fruits registered a production of 20,678 MT or an equivalent of 
$5.4 \%$. Root crops produced were 2,965 MT, and legumes production was $1,513 \mathrm{MT}$. Total crop production was valued at P5,429,133,000.00 [9]

Table 1. Agricultural Production and Value of Produce in Ilocos Sur in 2012

\begin{tabular}{|c|c|c|c|}
\hline Commodity & Production & $\begin{array}{l}\text { Cost } \\
\text { per Kg } \\
\end{array}$ & $\begin{array}{l}\text { Value of } \\
\text { Produce }\end{array}$ \\
\hline & (MT) & (Php) & (000 Php) \\
\hline Palay & 209977 & 15 & $3,149,655$ \\
\hline Corn & 76719.5 & & $1,017,674$ \\
\hline Root Crops & 2510 & & 86,062 \\
\hline Camote & 1230 & 10 & 12,300 \\
\hline Cassava & 300 & 10 & 3,000 \\
\hline Gabi & 980 & 10 & 9,800 \\
\hline Legumes & 1513 & & 107,820 \\
\hline Mungo & 418 & 27 & 38,880 \\
\hline Peanut & 1095 & 20 & 68,940 \\
\hline Vegetables & 75298 & & $1,071,035$ \\
\hline Leafy & 14440 & & \\
\hline Stringbeans & 2183 & 15 & 32,745 \\
\hline $\begin{array}{l}\text { Sweet } \\
\text { Pepper }\end{array}$ & 1160 & 10 & 11,600 \\
\hline $\begin{array}{l}\text { Finger } \\
\text { Pepper }\end{array}$ & 900 & 20 & 18,000 \\
\hline Tomato & 26213 & 10 & 262,130 \\
\hline Eggplant & 8119 & 10 & 81,190 \\
\hline Watermelon & 3000 & 15 & 45,000 \\
\hline Ampalaya & 3125 & 20 & 62,500 \\
\hline Upo & 550 & 10 & 5,500 \\
\hline Squash & 2350 & 10 & 23,500 \\
\hline Cabbage & 10040 & 20 & 200,800 \\
\hline Cauliflower & 4220 & 20 & 84,400 \\
\hline Garlic & 238 & 50 & 11,900 \\
\hline Onion & 14044 & 15 & 210,660 \\
\hline Patola & 485 & 10 & 4,850 \\
\hline Okra & 626 & 10 & 6,260 \\
\hline Ginger & 865 & 20 & 17,300 \\
\hline Fruits & 20678 & & 314,860 \\
\hline Mango & 8558 & 20 & 171,160 \\
\hline Avocado & 4500 & 15 & 67,500 \\
\hline Papaya & 1100 & 10 & 11,000 \\
\hline Jackfruit & 2350 & 10 & 23,500 \\
\hline Calamansi & 1170 & 10 & 11,700 \\
\hline Chico & 1400 & 10 & 14,000 \\
\hline
\end{tabular}

Based on the table above, palay and corn are the most planted crops in Ilocos Sur. Vegetables are coming in third based on crop type. With these findings, these top crops were evaluated for cropping intervals.

\section{Crop Selection}

Based on several kinds of literature and local practices in Ilocos Sur, planting palay for two cropping season and corn in the dry season is a viable option of optimizing land use. It is now logical to see that these two crops are top ones in Ilocos Sur because they can be planted in this way.

Table 2. Proposed Planting Schedule for Rice and Corn

\begin{tabular}{|l|l|l|l|l|l|l|l|l|l|l|l|l|}
\hline & J & F & M & A & M & J & J & A & S & O & N & D \\
\hline Rice1 & & & & & & & & & & & & \\
\hline Rice2 & & & & & & & & & & & & \\
\hline Corn & & & & & & & & & & & & \\
\hline
\end{tabular}

Based on several kinds of literature and local practices in Ilocos Sur, planting palay for two cropping season and corn in the dry season is a viable option of optimizing land use. It is now logical to see that these two crops are top ones in Ilocos Sur because they can be planted in this way.

Based on FAO, the average plant growth of rice is up to 5 months while corn is up to 4 months. To be able to squeeze three croppings in a year, ricegrowing shall be limited to 4 months. Based on the table above. The first planting season for rice will start in May, around the start of the rainy season in Ilocos Sur, and harvesting will be in September, Second planting shall immediately commence on the same month and end in January. The month of February has little rainfall and just in time for Corn planting as it requires a minimal amount of water at the beginning. Corn harvesting shall be in May.

\section{Water requirement}

Table 3 summarizes the irrigation requirements of the crops to be planted together with the sources of irrigation. Rainfall data for 2019 was taken from PAGASA[10]. The monthly irrigation requirement for rice is based on the recommendation of Tamil Nadu Agricultural University[11]. Irrigation requirement for corn was taken from a study at the University of Georgia in 2016 [12]. The water volume 
requirement is computed based on the difference between the rainfall and the total irrigation requirement.

Table 3. Rainfall data, and water requirements of proposed crops

\begin{tabular}{|c|c|c|c|c|c|c|c|}
\hline \multirow{2}{*}{ Month } & \multirow{2}{*}{$\begin{array}{l}\text { Rain- } \\
\text { fall } \\
\text { data } \\
2019 \text {, } \\
\text { mm }\end{array}$} & \multicolumn{4}{|c|}{$\begin{array}{c}\text { Irrigation Requirement, } \\
\text { mm }\end{array}$} & \multicolumn{2}{|c|}{$\begin{array}{l}\text { Water volume } \\
\text { required }\end{array}$} \\
\hline & & $\begin{array}{c}\text { Rice } \\
1\end{array}$ & $\begin{array}{c}\text { Rice } \\
2\end{array}$ & Corn & Total & $\begin{array}{r}\text { From } \\
\text { pump } \\
\text { mm }\end{array}$ & $\begin{array}{r}1 \text { ha } \\
\text { land, } \\
\text { m3 }\end{array}$ \\
\hline Jan & 5.4 & & 125 & & 125 & 119.6 & 1196 \\
\hline Feb & 0.1 & & & 33 & 33 & 32.9 & 329 \\
\hline Mar & 8 & & & 151 & 151 & 143 & 1430 \\
\hline Apr & 37 & & & 245 & 245 & 207.8 & 2078 \\
\hline May & 342 & 40 & & 214 & 254 & & \\
\hline Jun & 294 & 200 & & & 200 & & \\
\hline Jul & 406 & 458 & & & 458 & 52.1 & 521 \\
\hline Aug & 1015 & 417 & & & 417 & & \\
\hline Sep & 529 & 125 & 40 & & 165 & & \\
\hline Oct & 68 & & 200 & & 200 & 132.3 & 1323 \\
\hline Nov & 250 & & 458 & & 458 & 208.1 & 2081 \\
\hline Dec & 57 & & 417 & & 417 & 360 & 3600 \\
\hline & Total & & & & & 1255.8 & 12558 \\
\hline
\end{tabular}

\section{Irrigation costs using conventional methods}

In Ilocos Sur, the most common way to irrigate is thru the use of the gasoline engine water pump, more commonly, a 5 hp pump is used. Table 4 shows the specification of a typical water pump used and shall be used as a basis for computation in the study:

Table 3.Robin water pump technical/nameplate specifications [13]

\section{LONFA Robin Water Pump}

Self-priming centrifugal gasoline water pump Technical Parameters

\begin{tabular}{lcc} 
Model & PTG210 & PTG310 \\
\hline Suction * Delivery (mm) & $50 * 50$ & $80 * 80$ \\
Suction * Delivery (inch) & $2 * 2$ & $3 * 3$ \\
Total Head (m) & 46 & 32 \\
Suction Head (m) & 8 & 8 \\
Max Delivery Vol.(m $/ \mathrm{h})$ & 36 & 60 \\
Engine Model & ADEY20/5.0hp \\
Fuel tank capacity (L) & \multicolumn{2}{c}{$3.8 \mathrm{~L}$} \\
Starting System & \multicolumn{2}{c}{ Hand start } \\
Packing Size & \multicolumn{2}{c}{$495^{*} 380 * 440$} \\
$\quad\left(\mathrm{~L}^{*} \mathrm{~W}\right) \mathrm{Hm}$ & 26 & 28 \\
Net Weight $(\mathrm{kg})$ & \multicolumn{2}{c}{}
\end{tabular}

The Robin PTG210 type is enough for most irrigation needs in Ilocos Sur due to its high head capacity. The current price of the equipment is PHP 15,000 [14]. Table 5 summarizes initial values and assumptions for computation

Table 4. Referenced and assumed values as the basis for water cost computation using the gasoline engine

\begin{tabular}{lr}
\hline Description & Value/Assumption \\
\hline Pump Max Capacity & $36 \mathrm{cu} . \mathrm{m} / \mathrm{hr}$ \\
Fuel cost & $47 \mathrm{PHP} / 1$ \\
Cost & $\mathrm{PHP} 15,000$ \\
Calorific value & $45,000 \mathrm{~kJ} / \mathrm{kg}[15]$ \\
Fuel density & $0.7489 \mathrm{~kg} / \mathrm{l}[16]$ \\
Manpower Salary & $200 \mathrm{PHP} / \mathrm{day}$ \\
Manpower requirement & $6 \mathrm{man}-$ days $/ \mathrm{mo}$ \\
Accessories & \\
$\quad$ (hoses, adaptors, etc) & $\mathrm{PHP} \mathrm{5000}$ \\
Overall engine efficiency & $20.5 \%[17]$ \\
Inflation rate & $5 \%$ \\
\hline
\end{tabular}

The fuel cost were computed in terms of cubic meter of water to liter of fuel to be used. It was also be assumed for the basis of computation that the pump will be running at its peak load of 36 cu.m/hr.

To compute for the fuel required in one (1) hr to operate the engine at max load, the total energy required was first be computed, thus

\section{Total Power required $=$ Total HP $x \quad 0.746 \mathrm{~kW} / \mathrm{HP}$ $=5 \times 746$$$
=3.730 \mathrm{~kW} \quad \text { or } \quad 3.730 \mathrm{~kJ} / \mathrm{s}
$$ \\ Total Energy required $=$ Total $\mathrm{kJ} / \mathrm{s} \quad x 3600 \mathrm{~s}$ $=13,428 \mathrm{~kJ}$}

To get the amount of fuel required

$$
\begin{aligned}
& \text { Total fuel required } \\
& =\text { Total Energy/Efficiency/Calorific Value } \\
& =[13,428 \mathrm{~kJ}] /[0.205] /[45,000 \mathrm{~kJ} / \mathrm{kg}] \\
& \quad \mathrm{x}[0.7489 \mathrm{~kg} / \mathrm{l}] \\
& =1.944 \text { liters }
\end{aligned}
$$

Thus, it requires 1.944 liters of fuel to produce 36 cubic meters or 0.534 liters of fuel to produce 1 cubic meter of water. In one year the total cost 
pump all the required 1225.8 liters shall be $1225.8 \times 47$ Pesos $=57,612$ Pesos.

\section{Irrigation costs using conventional methods}

A year table were generated to determine the cash flow. The following were assumed:

On year 1

- Purchase of water pump and accessories

- Maintenance cost

- Fuel cost

- Manpower

On year 2 to 20

- Maintenance cost

- Fuel cost

- Manpower

It will be assumed that there will be an additional investment required from year 2 to 20 . After year 20 , the pump and accessories shall be considered to be fully depreciated and will have no value. The table below summarizes the computation, with the costs in year 2-20 reflected as present values with to inflation rate factored in. To be able to compare the "production cost" the cost of pumping one cubic meter of water were determined.

Table 5. Cash flow analysis on the usage of gasoline-fueled water pump over 1 hectare of land

\begin{tabular}{|c|c|c|}
\hline \multirow[t]{2}{*}{ Description } & \multicolumn{2}{|c|}{ Expense Cost } \\
\hline & Year 1 & Year 2-20 \\
\hline Gasoline pump & 15000.00 & \\
\hline Water Tank & 0.00 & \\
\hline Manpower & 9400.00 & 9400.00 \\
\hline Accessories & 2000.00 & \\
\hline Maintenance Cost & 500.00 & 500.00 \\
\hline Fuel Cost & 57612.00 & 57612.00 \\
\hline Total & 84152.00 & 67512.00 \\
\hline \multicolumn{2}{|c|}{ Total Cost for 20 years } & 1367240 \\
\hline \multicolumn{2}{|c|}{ Total water pumped for 20 years } & 251160 \\
\hline \multicolumn{2}{|c|}{ Cost per $\mathrm{m}^{3}$ pumped, PHP } & 5.44 \\
\hline
\end{tabular}

Based on the table above, the cost of pumping one cubic meter of water is PHP 5.44, factoring in all equipment, fuel, maintenance cost, and manpower.

\section{Irrigation costs Solar water pump}

Irrigation using a solar water pump requires infrastructure to be constructed at the site. This requires an installation of a solar water pump facility, a shed with installed solar panels, and a water storage facility located at the higher elevation side of the land, with the water dispatch shall be done through gravity.

To size up the solar water pump, the maximum water requirement throughout the year was determined. Based on the table showing water requirements, the month of December shows the highest demand at 360 liters. Determining the daily average output,

\section{Daily output required

$$
=360 \mathrm{~m}^{3} / 30 \text { days }=60 \mathrm{~m}^{3} \text { per day }
$$

Assuming around 4 sun hours per day, the required capacity was 15 cubic meters per hour. Based on the manufacturer specification below the following type were picked

DC pump model: 4JTSC15/70-D72/1300

$\begin{array}{ll}\text { Pump power: } & 1300 \mathrm{w} \\ \text { Water flow } & 15 \mathrm{~m} 3 / \mathrm{hr} \\ \text { Water head } & 78 \mathrm{~m}\end{array}$

Table 6. Sample of Catalog of DC solar pumps of [greensunsolar brand]

\begin{tabular}{|c|c|c|c|c|c|}
\hline$\overline{\mathrm{DC}}$ & Pump & $\overline{\overline{\text { Wat }}}$ & Water & & Veigh \\
\hline & $\begin{array}{r}\text { Power } \\
\text { (watt) }\end{array}$ & $\begin{array}{l}\text { Flow } \\
\left(\mathrm{m}^{3} / \mathbf{h}\right)\end{array}$ & $\begin{array}{c}\text { Head } \\
(\mathbf{m})\end{array}$ & (inch) & $(\mathbf{k g})$ \\
\hline $\begin{array}{c}3 \mathrm{JTS}(\mathrm{T}) 1.0 / 30- \\
\text { D24/80 }\end{array}$ & 80 & 1.0 & 30 & 0.75 & 7 \\
\hline $\begin{array}{c}3 \mathrm{JTS}(\mathrm{T}) 1.5 / 80- \\
\text { D24/210 }\end{array}$ & 210 & 1.5 & 80 & .75 & 7.5 \\
\hline $\begin{array}{c}3 \text { JTS (T)2.3/80- } \\
\text { D48/750 }\end{array}$ & 750 & 2.3 & 80 & 15 & 9 \\
\hline $\begin{array}{l}\text { 4JTS3.0/60- } \\
\text { D36/500 }\end{array}$ & 500 & 3 & 60 & 1 & 10 \\
\hline $\begin{array}{l}\text { 4JTS3.8/95- } \\
\text { D72/1000 }\end{array}$ & 1000 & 3.8 & 95 & $1 .($ & 13.5 \\
\hline $\begin{array}{c}\text { 4JTS4.2/110- } \\
\text { D72/1300 }\end{array}$ & 1300 & 4.2 & 110 & 1.0 & 14 \\
\hline $\begin{array}{c}\text { 3JTSC6.5/80- } \\
\text { D72/1000 }\end{array}$ & 1000 & 6.5 & 80 & $1.25 "$ & 14.5 \\
\hline $\begin{array}{c}\text { 3JTSC7.0/140- } \\
\text { D192/1800 }\end{array}$ & 1800 & 7.0 & 140 & $1.25^{\prime \prime}$ & 17.5 \\
\hline $\begin{array}{c}\text { 3JTSC7.0/180- } \\
\text { D216/2200 }\end{array}$ & 2200 & 7.0 & 180 & $1.25^{\prime \prime}$ & 15.5 \\
\hline $\begin{array}{c}\text { 4JTSC15/70- } \\
\text { D72/1300 }\end{array}$ & 1300 & 15 & 70 & $2.0 "$ & 14 \\
\hline
\end{tabular}




\begin{tabular}{cccccc}
\hline 4JTSC22/90- & 3000 & 22 & 90 & $2.0 ”$ & 14 \\
D216/3000 & & & & & \\
$\begin{array}{c}\text { 4JTSC25/125- } \\
\text { D380/5500 }\end{array}$ & 5500 & 25 & 125 & $2.0 ”$ & 16.5 \\
$\begin{array}{c}\text { 6JTSC35/45- } \\
\text { D216/2200 }\end{array}$ & 2200 & 35 & 45 & $3.0 ”$ & 16 \\
$\begin{array}{c}\text { 6JTSC33/101- } \\
\text { D380/7500 }\end{array}$ & 7500 & 33 & 101 & $3.0 ”$ & 22.5 \\
$\begin{array}{c}\text { 6JTSC68/44- } \\
\text { D380/5500 }\end{array}$ & 5500 & 68 & 44 & $4.0 ”$ & 23.5 \\
$\begin{array}{c}\text { 6JTSC68/58- } \\
\text { D380/7500 }\end{array}$ & 7500 & 68 & 58 & $4.0 ”$ & 25 \\
\hline
\end{tabular}

Assuming that water irrigation shall only happen during the daytime to maximize solar power, irrigation time shall be considered to be 6 am - 5 $\mathrm{pm}$. This is to maximize the full potential of the solar pump while minimizing storage size.

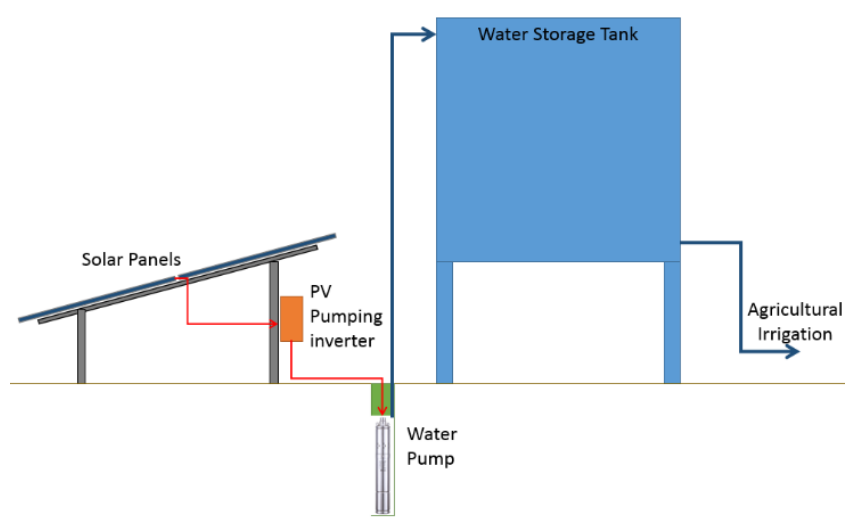

Figure 1. Equipment Design

\section{Method of Construction:}

1. Mounting Structure of the PV Modules: the frame shall be made with 1"x1" angle bar with the PV modules to face south, azimuth at zero degrees, tilted at a 15-degree angle.

2. Frame feet shall be made of concrete ballast or to be rammed into the ground. Concrete ballast volume shall be determined in the study based on the uplift forces caused by high wind surges. If rammed, the depth shall be established to counter high wind uplift forces.

3. The storage tank shall be made concrete with waterproofing liners. It will be preferable to be located in the higher elevation side of the farm and slightly elevated to around $1 \mathrm{~m}$.

4. Inverter Location: the Inverter pump to be used shall usually be IP65-rated. However,
Inverters shall be placed underneath the PV modules.

5. Electrical wiring: DC cables shall be XLPE type, $4-6 \mathrm{~mm} 2$ size.

6. For the water tank size, a series of the simulation was made to determine the optimal storage size. The figure below shows that a 30L storage capacity is ideal for the situation. Water tank cost shall be conservatively estimated at PHP 50,000.

7. Figure 2 shows the external dimension of the water tank, slightly elevated by 1 meter with a water volume capacity of 30 cubic meters.

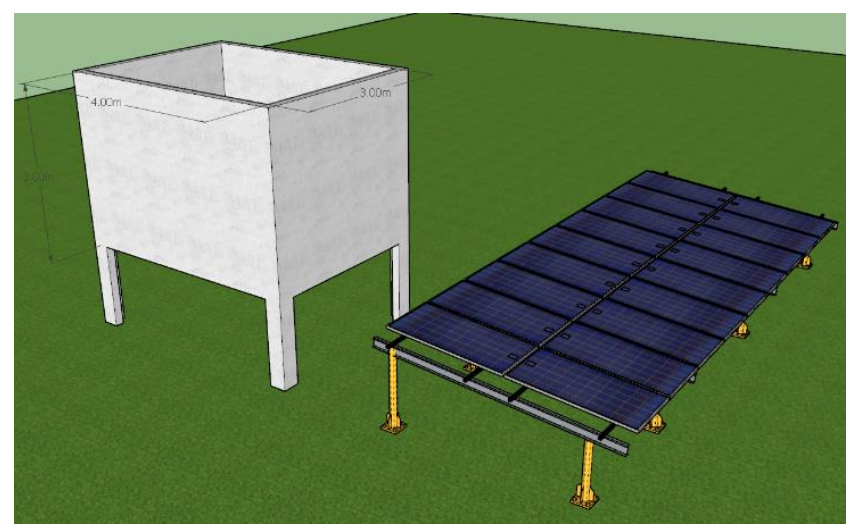

Figure 2. Water tank dimensions

In the Figure 3, the curve was modelled based on a 30-liter storage tank. It is shown that the tank capacity dips to only 5 liters by 11 AM, leaving room for uncertainties in the weather and water requirement. The tank shall be full be around 2 pm. Usage and water pump will stop at about 6-7 $\mathrm{pm}$ and will retain 25 -liter water in the tank.

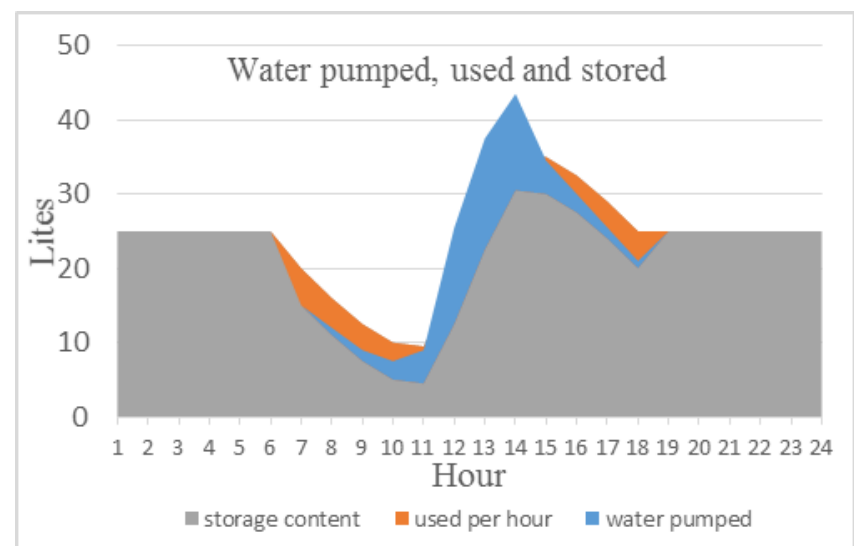

Figure 3. Water storage pumped in and used over 24 hour period 
For the water flow, assuming that the irrigation system shall use a single 2" pipe tubing, water volume output is computed based on the law of conservation of energy.

Volume offlow

$$
=\text { cross section area of pipe } x \text { water speed }
$$

For maximum water speed

$$
\begin{aligned}
& \nu=\sqrt{(2 g h)} \\
& =\quad 7 \mathrm{~m} / \mathrm{s} \text { or } 25200 \mathrm{~m} / \mathrm{hr}
\end{aligned}
$$

For maximum Volume flow

$$
\begin{array}{ll}
Q=\left(\pi d^{2}\right) / 4 \times v \\
=\quad 3.14 \times 0.0508^{2} / 4 \times 25200 \\
=\quad 51 \text { cubic meter } / \mathrm{hr}
\end{array}
$$

This would indicate that the maximum volume flow that can be achieved is above the required flow of 11 cubic meters per second

For the number of PV modules, the quantity were based on the pump capacity of 1100W. The current performance ratio of solar PV installations is at $70-80 \%$. Using conservative PR of $70 \%$, the required size is

\section{Required PV installation size}

$$
\begin{aligned}
& =\text { Pump capacity } / \text { estimated } P R \\
& =1100 \mathrm{~W} / .7 \\
& =1571 \mathrm{~W}
\end{aligned}
$$

The typical size in the market right now is 305$315 \mathrm{Wp}$ Polycrystalline modules. Using $5 \mathrm{x}$ $315 \mathrm{Wp}=1575 \mathrm{Wp}$ capacity of modules, it will be more than sufficient to run the $1100 \mathrm{~W}$ DC pump.

The PV modules shall be installed in a steel racking system with the modules tilted 15 degrees facing south.

Table 7. Cash flow analysis on the usage of solar water pump over 1 hectare of land

\begin{tabular}{lrr}
\hline \hline Description & \multicolumn{2}{c}{ Expense Cost } \\
\hline & \multicolumn{1}{c}{ Year 1 } & Year 2-20 \\
PV pump, wiring, & 40000.00 & \\
PV Solar modules & 40000.00 & \\
315Wp x 5 & & \\
PV racking system & 10000.00 & \\
Water Tank 30L & 50000.00 & 9400.00 \\
Manpower & 9400.00 & 9400.00 \\
Accessories & 2000.00 & \\
Maintenance Cost & 500.00 & 500.00 \\
Fuel Cost & 0 & 0
\end{tabular}

Total

84152.00

67512.00

Total Cost for 20 years

340000

Total water pumped for 20 years

251160

Cost per $\mathrm{m}^{3}$ pumped, PHP

1.35

Based on the table above, it shows that the cost of producing one cubic meter of water is only PHP 1.35 .

\section{Conclusion and recommendation}

The study showed that common crops in Ilocos Sur like rice and corn could be alternately be planted to be able to maximize the full potential of the land. This, in turn, would be able to optimize the use of the water pump, whether gasoline or solar pump.

With the gasoline pump usage turning out to be low cost at the beginning but with high operating and maintenance cost, the opposite goes for the solar pump. Solar pumps have a high upfront cost but little to no maintenance cost. As a result of this study, the use of a solar pump is cheaper in the long run. In the 20-year life of both equipment, pumping one cubic meter of water using a solar pump is only PHP 1.35 while for gasoline, it is PHP 5.44 or around four times more expensive.

\section{Acknowledgement}

The authors would like to thank the Ilocos Sur Polytechnic State College for the financial support to this research. The first and third authors would also like to thank the second author for the additional financial and technical support for the completion of this paper.

\section{References (APA $6^{\text {th }}$ edition)}

[1] IRENA (The International Renewable Energy Agency) (2015) Solar pumping

[2] B.Shanthi Saravana, Dr.V.Rajini, and A.Paramasivam, "Analyzing Wind Power Potential in Cauvery Delta areas for Implementation of Renewable Energy based Standalone Pumping System for Irrigation", IERI Procedia, Vol. 5, pp. 153 - 160, 2013.

[3] Robert Foster and Alma Cota, "Solar water pumping advances and comparative economics", Energy Procedia, Vol. 57, pp. $1431-1436,2014$. 
[4] S.S. Chandel, M. Nagaraju Naik, and Rahul Chandel, "Review of solar photovoltaic water pumping system technology for irrigation and community drinking water supplies", Renewable and Sustainable Energy Reviews, Vol. 49, pp. 1084-1099, 2015.

[5] IRENA (The International Renewable Energy Agency) (2015) Solar pumping

[6] B.Shanthi Saravana, Dr.V.Rajini, and A.Paramasivam, "Analyzing Wind Power Potential in Cauvery Delta areas for Implementation of Renewable Energy based Standalone Pumping System for Irrigation", IERI Procedia, Vol. 5, pp. 153 - 160, 2013.

[7] Robert Foster and Alma Cota, "Solar water pumping advances and comparative economics", Energy Procedia, Vol. 57, pp. 1431 - 1436, 2014.

[8] S.S. Chandel, M. Nagaraju Naik, and Rahul Chandel, "Review of solar photovoltaic water pumping system technology for irrigation and community drinking water supplies", Renewable and Sustainable Energy Reviews, Vol. 49, pp. 1084-1099, 2015.

[9] Imene Yahyaoui, Giuseppe Tina, Maher Chaabene and Fernando Tadeo, "Design and Evaluation of a Renewable Water Pumping System", IFAC- Conference paper archive, ScienceDirect, Papers On-Line, Vol. 48, No. 30, pp. 462-467, 2015.

[10] Ahmad Agus Setiawana, Didik Hari Purwantoa, Didit Setyo Pamujia, and Nurul Hudaa, "Development of a Solar Water Pumping System in Karsts Rural Area Tepus, Gunungkidul through Student Community Services", Energy Procedia, Vol. 47, pp. 7 14, 2014.

[11] Francisco J. Chueco-Fernández and Ángel A. Bayod-Rújula, "Power supply for pumping systems in northern Chile: Photovoltaics as alternative to grid extension and diesel engines", Energy, Vol. 35, No. 7, pp. 29092921, 2010.

[12] Elham Mahmoud and Hossen El Nather, "Renewable energy and sustainable developments in Egypt: photovoltaic water pumping in remote areas", Applied Energy, Vol. 74, No. 1-2, pp. 141 - 147, 2003.

[13] Provincial Agriculture Office, Vigan City: 2012. https://www.ilocossur.gov.ph/index.php/geninfo/2016-07-27-03-35-14/2016-07-27-03-3602. Feb 23, 2012
[14] PAGASA, 2019. http://pubfiles.pagasa.dost.gov.ph/climps/clim ateforum/climatereview.pdf

[15] Directorate of Extension Education, Tamil Nadu Agricultural University, Coimbatore, Tamil Nadu. http://www.agritech.tnau.ac.in/expert_system/ paddy/Index.html

[16] University of Georgia, 2016. https://site.extension.uga.edu/colquittag/2016/ 06/southern-rust-and-corn-irrigationtermination/

[17] Longapower Robin Equipment catalog. http://www.longfapower.com/5-0HP-EY20ROBIN-DESIGN-GASOLINE-WATERPUMP-pd737324.html 